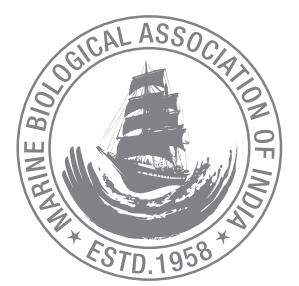

\title{
A taxonomic revision of the fishes of the Genus Bleekeria (Perciformes, Ammodytidae)
}

\author{
M. S. Varsha*, M. Sethulakshmi, Hitoshi Ida ${ }^{1}$, John E. Randall ${ }^{2}$ and K. K. Joshi \\ ICAR-Central Marine Fisheries Research Institute, Kochi, 682 018, Kerala, India. \\ ${ }^{1}$ School of Marine Biosciences, Kitasato University, 252-0373, Kitasato 1-15-11, Japan. \\ 2 Bishop Museum, 1525 Bernice, St. Honolulu, USA. \\ *Correspondence e-mail:varshashaji88@gmail.com
}

Received: 10 Jan 2019 Accepted: 25 Jan 2019 Published: 30 Jan 2019

Original Article

\begin{abstract}
Fishes of the family Ammodytidae popularly known as sand lances or sand eels, feed in aggregations on zooplankton over open sand bottom. The Ammodytidae consists of seven genera and two common genera Bleekeria and Ammodytes. There are 11 species recorded in the genus Bleekeria of which only six are valid. The valid ones are Bleekeria kallolepis, B. mitsukurii, B. viridianguilla, B. murtii, B. profunda and B. estuaria. A key for the identification of Bleekeria is prepared. We compared details of the types of all six species of Bleekeria and reviewed the genus Bleekeria. The details of holotype of $B$. viridianguilla at Academy of Natural Sciences, Philadelphia, USA, B. kallolepis at Natural History Museum, London, B. mitsukurii at Californian Academy of Sciences, California, USA, and B. murtii at CMFRI, Museum, Kochi, India, B. profunda and B. estuaria at South African Institute for Aquatic Biodiversity were collected and compared.
\end{abstract}

Keywords: Sand eel, Ammodytidae, Bleekeria, species key, taxonomy, genus revision

\section{Introduction}

Small, slender fishes of the family Ammodytidae popularly known as sand lances, feed in aggregations on zooplankton over open sand bottom (Randall and Heemstra, 2008). They are a very interesting group of fishes adapted for zooplankton feeding such as protractible premaxilla, short snout for binocular vision, reduced dentition and long gill rakers. They have a special mechanism to escape with the help of pointed jaw and their fins are folded into grooves. The Ammodytidae consists of seven genera and two common genera are Bleekeria and Ammodytes. There are about 11 species recorded in the genus Bleekeria of which only three were valid until 2012. The valid ones are Bleekeria kallolepis Günther 1862, B. mitsukurii Jordan and Evermann 1902 and B. viridianguilla Fowler, 1931. Joshi et al. (2012) described a new species Bleekeria murtii from the Gulf of Mannar, India. Randall and Ida (2014) described two new species $B$. profunda and $B$. estuaria. According to Eschmeyer et al. (2017) there are about 11 species recorded in the genus Bleekeria of which only six are valid. The valid ones are $B$. kallolepis Günther 1862; $B$. mitsukurii Jordan and Evermann 1902; B. viridianguilla Fowler, 1931; B. murtii Joshi, Zacharia \& Kanthan, 2012; B. profunda Randall and Ida, 2014 and B. estuaria Randall and Ida, 2014. 
The other genus in the family Ammodytidae i.e. the Ammodytes has five species and enjoys wide distribution and abundance (Belgium, Denmark, France, Germany, Ireland, Netherlands, Norway, Poland, Russia and U.K.). But this genus mainly occurs in the subtropical and Arctic Seas. In the tropical seas, Ammodytes is replaced by much smaller genera like Bleekeria and Hyperoplus which are characterized by smaller bodies and lesser number of vertebrae and presence of teeth. These tropical species must have been detached from the Ammodytidae to form distinct genus Bleekeria. Although three species have been described earlier in the genus, all of them are poorly known and type status is uncertain in some cases. Therefore, here is an attempt to revise the genus Bleekeria comprising six pecies belong to the family Ammodytidae. We compared details of the types of all six species of Bleekeria and reviewed the genus Bleekeria. Although six species have been described in the genus, three of them are poorly known and needs a comprehensive account of all the species. The present paper attempts to give revision of the lesser known genus Bleekeria of Ammodytidae for the easy identification of all the species for the purpose of fishery management and biodiversity conservation.

\section{Material and methods}

Details of the morphometric and meristic parameters of Bleekeria murtii were taken from Joshi et al., 2012. Diagnostic characters of the types of all the other four species of Bleekeria were compared using the holotype descriptions. The details of holotype B. viridianguilla, Fowler, 1931 (ANSP 53458) at Academy of Natural Sciences, Philadelphia, USA; B. kallolepis Günther, 1862 (BMNH 1846.11.22) at Natural History Museum, London; B. mitsukurii Jordan and Evermann, 1902 (SU7133) at Californian Academy of Sciences, California, USA; and B. murtii, Joshi, Zacharia and Kanthan, 2012 (CMFRI, GB.5.1.1) at CMFRI, Museum, Kochi, India, were compared in the present work. Details of $B$. profunda Randall and Ida, 2014 (SAIAB 84114) and $B$. estuaria Randall and Ida, 2012 were taken from Randall and Ida (2012) thus makes a total of six species.

A key to the genera was prepared for the easy identification of the genera. A species identification key for the six species of Genus Bleekeria was prepared based on the attributes of body depth, dorsal fin rays, lateral line scales and eye diameter. The morphometric characters of the species were compared using the percentage of measurements as a percentage of SL and HL (Abraham et al., 2011). Diagnostic characters of each species have been prepared based on dorsal rays, lateral line scales, eye diameter, upper jaw, lower jaw, teeth and scales. A brief description of the species of Bleekeria has been prepared based on the holotype comparisons of six species of Bleekeria. Descriptions followed by the details of colour, distribution, and the remarks of the species. Line drawings of the six species were prepared using the specimen characteristics from holotype and descriptions.

\section{Results and discussion}

\section{Family: Ammodytidae}

The Ammodytidae consists of ten genera with seven valid genera and 33 species (Ida et al., 1994; Collette and Randall, 2000; Randall and Earle, 2008). Bleekeria gilli was the first species of Ammodytoides described from the Pacific Ocean by Bean (1895). Bleekeria vaga was the second species described from Lord Howe Island by McCulloch and Waite (1916). Duncker and Mohr (1939) concluded that these species do not belong to Bleekeria and proposed the genus Ammodytes. Smith (1957) described a new species as Bleekeria rennie from the east coast of South Africa. Ida et al. (1994) revised the generic classification of the family, adding two more new genera and recognizing Bleekeria for three species, $B$. kallolepis Günther, 1862, B. mitsukurii Jordan and Evermann, 1902 and B. viridianguilla Fowler, 1931.

They have small cycloid scales, no spines in the fins, a long dorsal fin and no pelvic fins. Mouth large, lower jaw strongly projecting; upper jaw protractile, teeth present or absent. Gill rakers 22 to 32 . Dorsal fin continuous, with 36 to $67 \mathrm{soft}$ rays ; anal fin $1 / 2$ the length of dorsal fin with 14 to 35 soft rays. Caudal fin forked pectoral fin rays 13 to 17 . Pelvic fins rudimentary or absent.

Genus Bleekeria is closely related to Protammodytes and several characters are super imposed. Bleekeria can be easily distinguished from other genus by dorsal and anal ray counts.

Bleekeria: $34-49$ dorsal rays $+12-18$ anal rays

Protammodytes: $36-45$ dorsal rays $+15-18$ anal rays Lepidammodytes: $48-51$ dorsal rays $+17-19$ anal rays Ammodytoides: $44-53$ dorsal rays $+21-25$ anal rays Gymnammodytes: $49-58$ dorsal rays $+28-30$ anal rays. Ammodytes and Hyperoplus: 53-63 dorsal rays $+28-32$ anal rays.

Genus Bleekeria Günter, 1862

Type Species: Bleekeria kallolepis Günter, 1862

\section{Key to the species of Genus Bleekeria}

1a. Body depth lower than $9 \%$ SL, brightly coloured body 2

1b. Body depth higher than $9 \%$ SL, lightly coloured body. 3 
2a. Dorsal fin rays 40, lateral line scales 98-100, eye diameter $4.3 \% \mathrm{SL}$, back and upper body bluish, with five yellowish horizontal bands. Dorsal fins with bluish base and yellow bands and anal with a bluish band....... B. kallolepis

2b. Dorsal fin rays 40-42, lateral line scales 108-111, eye diameter $4.7 \% \mathrm{SL}$, back and upper body broccoli brown, sides and below pale vinaceous to whitish, no yellow bands, fins transparent without band. . B. viridianguilla

3a. Dorsal fin rays $42 \ldots \ldots \ldots \ldots \ldots \ldots \ldots \ldots$

3b. Dorsal fin rays above $42 \ldots \ldots \ldots \ldots \ldots$

4a. Dorsal fin rays 42 lateral line scales 90-109, eye diameter $4.0 \% \mathrm{SL}$, back and upper body greenish grey with yellow lines. Fins semitransparent . . . . . . . . . . . B. mitsukurii

4b. Dorsal fin rays 42 , lateral line scales 99 , eye diameter 4.3 in $\mathrm{HL} . . . \ldots \ldots \ldots \ldots \ldots$. . . . . . . . . . . . . . . . . . .

5a. Dorsal fin rays 35-49, lateral line scales 82-108, eye diameter $3.4 \% \mathrm{SL}$, Grayish yellow on back shading to silvery white laterally and ventrally with yellow bands, dorsal fin transparent and the interspace of rays has yellow bands...................... murtii

5b. Dorsal fin rays 49 , lateral line scales 151 , eye diameter 4.4. in $\mathrm{HL} \ldots \ldots \ldots \ldots \ldots \ldots$. . . . . . . . . . . . . .

\section{Description of the species of the Genus: Bleekeria}

\section{Bleekeria kallolepis Günter, 1862 (Fig.1, 2)}

Bleekeria kallolepis Günter, 1862. Catalogue of fishes in the British Museum V.4: 384 (type locality: Madras, India).

Fin formula: D.40, A. 14-16, L.I.98-110, Ltr. 3/14, GR 6+1+1920

Holotype: BMNH 1846.11.22.

Diagnosis: Dorsal fin rays 40, lateral line scales 98-100, eye diameter $4.3 \% \mathrm{SL}$, back and upper body bluish, with five yellowish horizontal bands. Dorsal fins with a bluish base and yellow bands and anal with a bluish band. The depth of the body is less than one-half of the length of the head, which is one-fifth of the total length.

Description: Eyes in the anterior half of the head. Head and

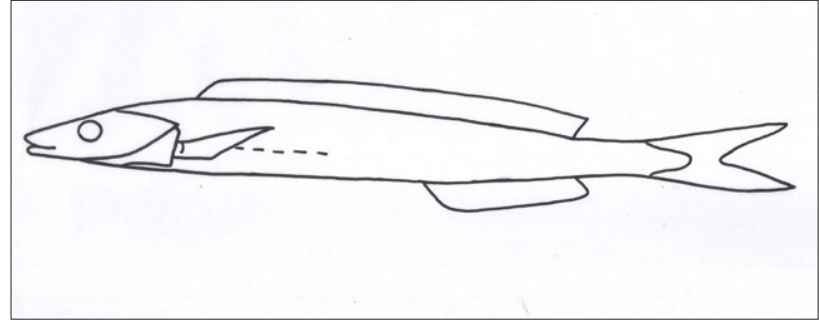

Fig. 1. Bleekeria kallolepis Günter, 1862

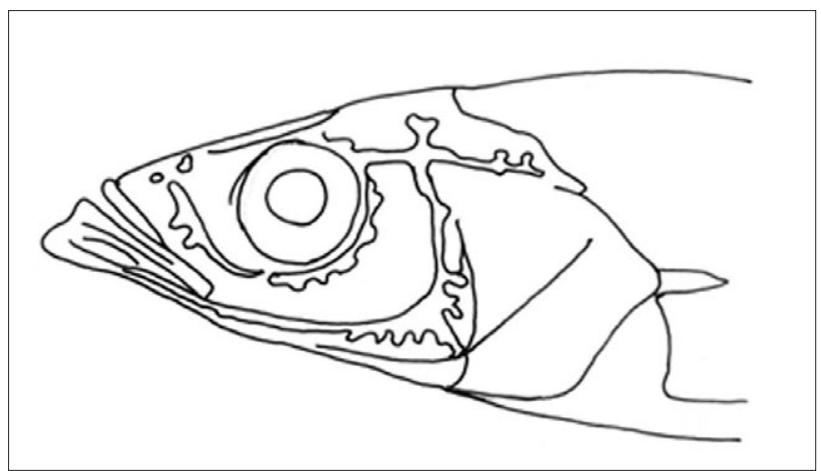

Fig. 2. Bleekeria kallolepis

body compressed. Lower jaw is prominent. Lower jaw slightly longer, the upper jaw protractile and the posterior limb of the premaxillaries reaching opposite the front edge of the orbit. Few fine teeth opposites to in either jaw. Dorsal fin commences above the first third of the pectoral and does not extend to the base of the caudal. No spines in the fins. Pectoral fin as long as the head behind the middle of the eyes. Anal fin commences below the last two-fifths of the dorsal. Caudal deeply forked. No scales on the head. Nostrils distant situated in the middle of the length of the snout.

Colour: Back and upper body bluish, lineated with about five yellowish horizontal bands. Dorsal fins with bluish base and yellow bands and anal with a bluish band along the centre.

Distribution: Along the coast of India, Srilanka and Thailand

Remarks: Günther (1862) described the second species of the genus Bleekeria kallolepis collected from Madras. According to Günther (1862) the body is less than one-half of the length of the head, which is one-fifth of the total of head and body together. It has a large eye. Günther was unable to detect any teeth in the jaws or on the palate. This species is reported from Thailand, India and Sri Lanka (Krishnan and Mishra, 1993) Holotype is available in the British Museum of Natural History (BMNH 1846.11.22).

Bleekeria kallolepis can be easily identifiable from other species by the presence of dorsal rays 40, lateral line scales 98-100, eye diameter $4.3 \% \mathrm{SL}$, back and upper body bluish, with five 
yellowish horizontal bands. Dorsal fins with bluish base and yellow bands and anal with a bluish band. Whereas Bleekeria viridianguilla can be easily distinguished from $B$. kallolepis by lateral line scales 108-111, eye diameter $4.7 \% \mathrm{SL}$, back and upper body broccoli brown, sides and below pale vinaceous to whitish, no yellow bands, fins transparent without a band.

Bleekeria mitsukurii: Dorsal rays 42, lateral line scales 90-109, eye diameter $4.0 \% \mathrm{SL}$, back and upper body greenish grey with yellow lines.

Bleekeria profunda: Dorsal rays 49, pectoral-fin ray's 16 , teeth present in the jaws, short pelvic fins (4.2 in HL) and 151 lateralline scales.

\section{Bleekeria viridianguilla Fowler, 1931}

(Fig.3, 4)

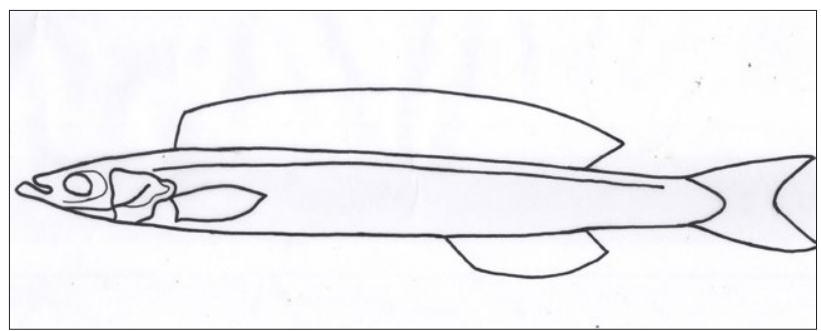

Fig. 3. Bleekeria viridianguilla (Fowler, 1931)

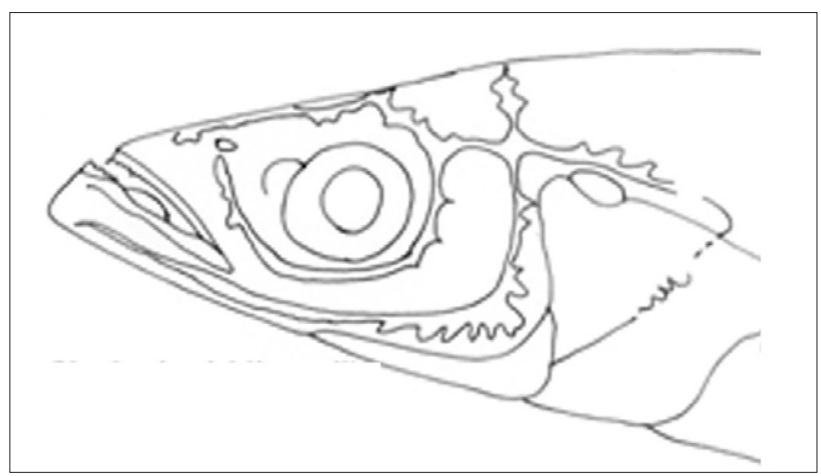

Fig. 4. Bleekeria viridianguilla

Herklotsina viridianguilla, Fowler, 1931 (Hong Kong Naturalist v.2 (4): 311, (type locality: Hong Kong).

Bleekeria viridianguilla (Fowler, 1931) Idea et al., 1994. Zoological studies 3394: 251-277.

Fin formula: D 40-42, A 14-16, Ltr. I. 108-114

Holotype: ANSP 53458, Paratypes: ANSP 53459-65.

Diagnosis: Body elongate; well compressed with a long caudal peduncle. Head moderate, well compressed. Eyes large anterior in head; premaxillaries very protractile; maxillary not reaching the eye. Lower jaw well developed; teeth in jaws indistinct, minute. Interorbital broad; gill rakers moderate; gill openings wide and membranes very narrow. Scale small; skins without folds. Dorsal long begins over the front of pectoral higher than body depth. Anal small; caudal moderately emarginated; pectoral larger than the post ocular region.

Description: Teeth simple. Conic narrow band in front of jaws. Interorbital five to six in head from snout tip, convex. Gill rakers $6+16$, lanceolate $11 / 4$ in gill filaments. Scales 108 to 114 in lateral line to caudal base and 2 to 4 more tubes. Caudal well covered with scales basally.

Colour: Back above broccoli brown, sides and below pale vinaceous to whitish. Iris silvery white, fins transparent.

Distribution: China, Taiwan, Australia, Hong Kong, Indonesia, Thailand

Remarks: The original description of $B$. viridianguilla (= Herklotsina viridianguilla) by Fowler, 1931 was from Hong Kong. This species is reported from China and Taiwan (Ida et al., 1994). Holotype of the species is ANSP 53458.

Bleekeria viridianguilla can be easily distinguished from other species by dorsal rays $40-42$, lateral line scales $108-111$, eye diameter $4.7 \% \mathrm{SL}$, back and upper body broccoli brown, sides and below pale vinaceous to whitish, no yellow bands, fins transparent without a band. $B$. viridianguilla has a large eye as compared to the small eye of the B. murtii, $34.1 \% \mathrm{HL}$ in the former and $17.4 \% \mathrm{HL}$ in the latter. The colour of $B$. viridianguilla is different from others with the back and upper body broccoli brown, sides and below pale vinaceous cinnamon to whitish with silvery white Iris. $B$. murtii resembles $B$. viridianguilla having an elongate body, long caudal peduncle, protractile premaxillaries and minute teeth.

In the case of $B$. kallolepis dorsal rays 40 ; lateral line scales 98-100; eye diameter $4.3 \%$ SL; back and upper body bluish; with five yellowish horizontal bands. Dorsal fins with bluish base and yellow bands and anal with a bluish band. While $B$. mitsukurii have dorsal rays 42; lateral line scales 90-109; eye diameter $4.0 \%$ SL; back and upper body greenish grey with yellow lines.

\section{Bleekeria mitsukurii Jordan and Evermann, 1902 (Fig. 5, 6)}

Bleekeria mitsukurii Jordan and Evermann, 1902. Proc. U.S.N.M. v.25 (1289):333. (type locality: Giran, Taiwan). 


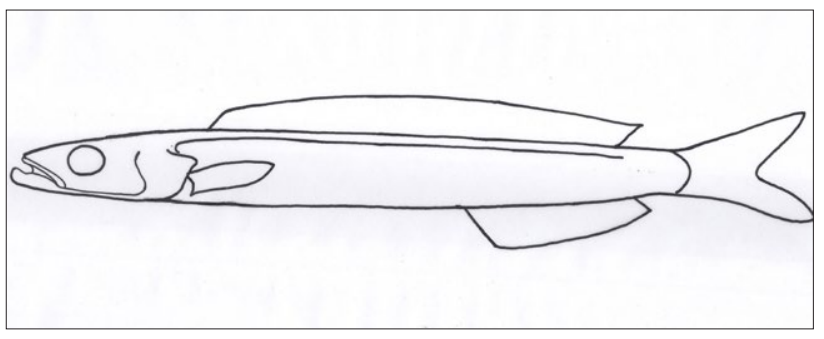

Fig. 5. Bleekeria mitsukurii (Jordan and Evermann, 1902)

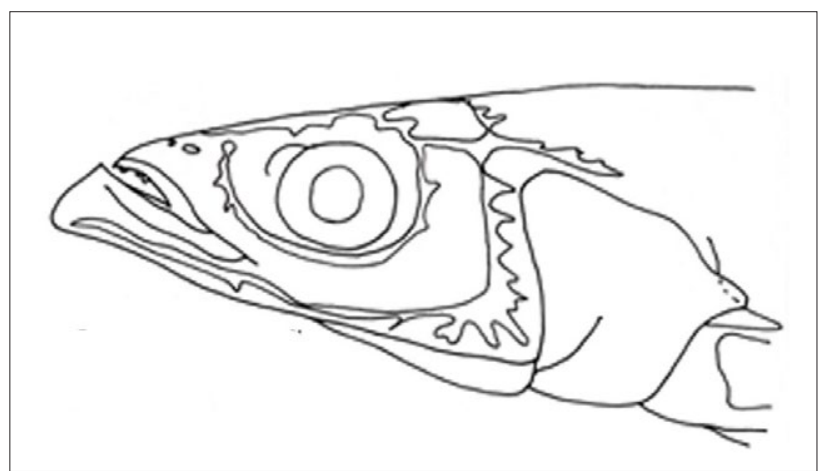

Fig. 6. Bleekeria mitsukurii

Embolichthys mitsukurii (Jordan and Evermann, 1902)

Holotype: SU 7133, SU 67143

Fin formula: D. 42, A. 14-16, Ltr. I.90-109

Diagnosis: : Dorsal rays 42, lateral line scales 90-109, eye diameter $4.0 \% \mathrm{SL}$, back and upper body greenish grey with yellow lines. Fins semitransparent. Body elongated, mouth terminal, large, lower jaw projecting, upper jaw protrusible, lateral line interrupted.

Description: Eyes in the anterior half of the head. Head compressed body with greater depth. Higher number of scale rows between lateral line and anal fin origin. The mouth protrusible and teeth present. Cycloid scales, the head, opercles, branchoistegal membranes and the isthmus are naked. Last interspinal of dorsal and anal are of two closely placed rays.

Distribution: Australia, Indonesia, Japan, New Caledonia, Taiwan

Remarks: The third species Embolichthys mitsukurii (=Bleekeria mitsukurii) was first described by Jordan and Evermann in 1902 from Giran. Lectotype designated by Pietzch and Zabetian in 1990. After that, several authors reported the same species from different localities (Jordan, 1903; Peitsch and Zebastian, 1990; Suzuki and Hosokawa, 1994; Goren and Dor, 1994; Collette, 2001; Nakabo, 2002) but mainly from Australia, Japan, Indonesia and Taiwan. Holotype of the species (SU7133, SU 67143).Of the three species in the genus Bleekeria mitsukurii described by Jordan and Evermann (1902) from Taiwan is most closely related to the present species but the colour pattern of $B$. mitsukurii is entirely different from $B$. murtii.

Bleekeria mitsukurii can be easily identified by dorsal rays 42; lateral line scales 90-109; eye diameter 4.0\% SL; back and upper body greenish grey with yellow lines. $B$. murtii the body depth is $10.55-15.45 \%(12.46)$ whereas it is $8.8 \%$ in B. viridianguilla, $10.0 \%$ in B. mitsukurii and $9.8 \%$ in $B$. kallolepis. The eye diameter showed a low range of 2.40 $4.46(3.63) \%$ SL as compared to the other species, whereas it is $4.74 \%$ in B.viridianguilla $4.0 \%$ in B. mitsukurii and $4.3 \%$ in $B$. kallolepis. The head length is shorter 17.9-23.8 (21.0) compared to $23.0 \%$ in $B$. viridianguilla, $34.1 \%$ in $B$. mitsukurii and $21.7 \%$ in B. kallolepis.

B. profunda have dorsal rays 49 , pectoral-fin rays 16 , teeth present in the jaws, short pelvic fins (4.2 in $\mathrm{HL}$ ) and 151 lateral-line scales.

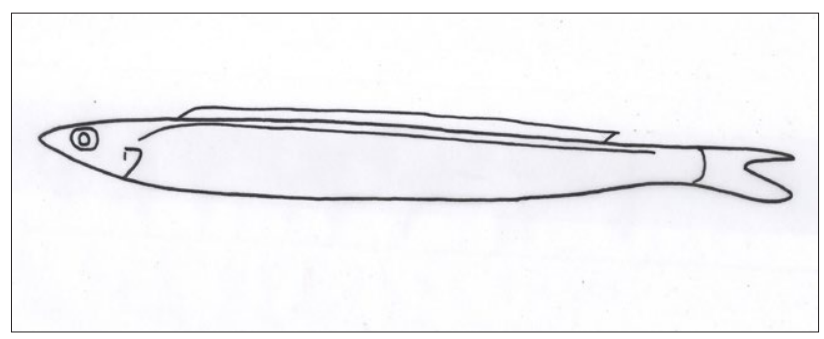

Fig. 7. Bleekeria estuaria Randall and Ida, 2014

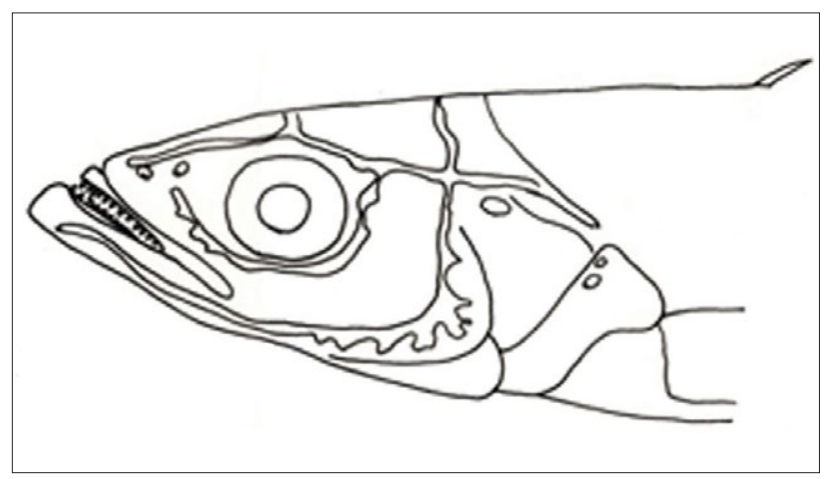

Fig. 8. Bleekeria estuaria

\section{Bleekeria estuaria Randall and Ida, 2014} (Fig. 7,8)

Bleekeria estuaria Randall and Ida, 2014. J. Ocean Sci. Found., 12:11. (type locality: Mozambique, Pomene Estuary)

Holotype: SAIAB 186240 
Fin formula: D.42, A.15, Ltr. I. 108-111.

Diagnosis: Dorsal-fin rays 42; anal-fin rays 15 ; pectoral-fin rays 14; pelvic fins absent; lateral-line scales 99 ; vertebrae 53; body depth 9.5 in SL; short head, eye moderately large, the upper-jaw length 3.35 in $\mathrm{HL} ; 22$ small, slender teeth on the side of the upper jaw, the scales dorsally on body to and including those of lateral-line scales very finely stippled with black; scales below lateral line with progressively less dark pigment; operculum with silvery patches; fin rays pale yellowish, the anterior edge of dorsal rays finely dotted with black; fin membranes translucent.

Description: Eyes moderately large; body sub- cylindrical; head and compressed body with a slight ventrolateral skin fold; the lower jaw strongly protruding extending medially one half eye diameter anterior to the mouth; mouth oblique, forming an angle of about $35^{\circ}$ to the horizontal axis of body; small, slender teeth in the upper and lower jaw; gill opening broad. dorsal line ray 42 ; anal fin rays 15 ; dorsal and anal rays segmented; pelvic fins absent; scale weakly ctenoid; lateral line scales 99; lateralis system on head complete; branchiostegal rays 7 ; origin of dorsal fin above tenth lateral line.

Color: Yellowish brown; scales with dark pigments; iris silvery white; fin rays pale; fin membranes translucent.

\section{Distribution: Mozambique}

Remarks: Bleekeria estuaria is one of six species of the genus. It may be distinguished from other species by having the shortest head; 4.9 in SL (shortest head for other species is 4.75 in SL, in B. murtii); the longest pectoral fins, 5.7 in SL (longest for other species is 7.35 in SL, in B. kallolepis); and by $3 / 17$ transverse scales (other congeners with more than $4 / 19$ transverse scales).

B. estuaria has 99 lateral-line scales whereas $B$. profunda has 49 dorsal rays, pectoral-fin ray's 16 , short pelvic fins (4.2 in $\mathrm{HL}$ ) and 151 lateral-line scales.

B. viridianguilla has 108-111 lateral line scales, eye diameter $4.7 \% \mathrm{SL}$, back and upper body broccoli brown, sides and below pale vinaceous to whitish, no yellow bands, fins transparent without band.

\section{Bleekeria murtii Joshi, Zacharia and Kanthan, 2012 (Fig. 9, 10)}

Bleekeria murtii Joshi, Zacharia \& Kanthan, 2012. Indian J. Fish., 59(2): 101-107, (type locality: Tuticorin, India).

Holotype: GB.5.1.1 in Designated National Repository, Central

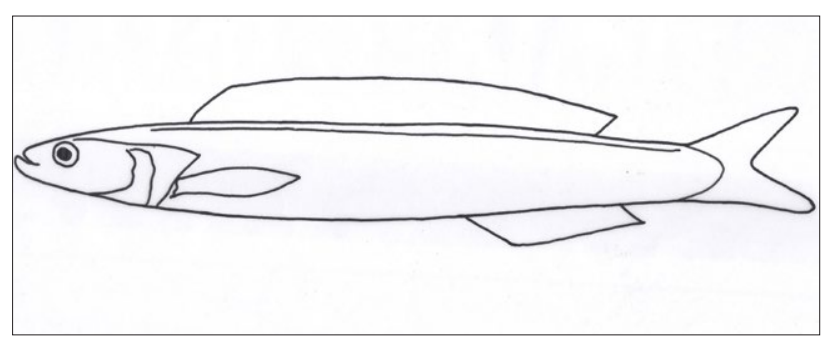

Fig. 9. Bleekeria murtii Joshi, Zacharia, Kanthan, 2012

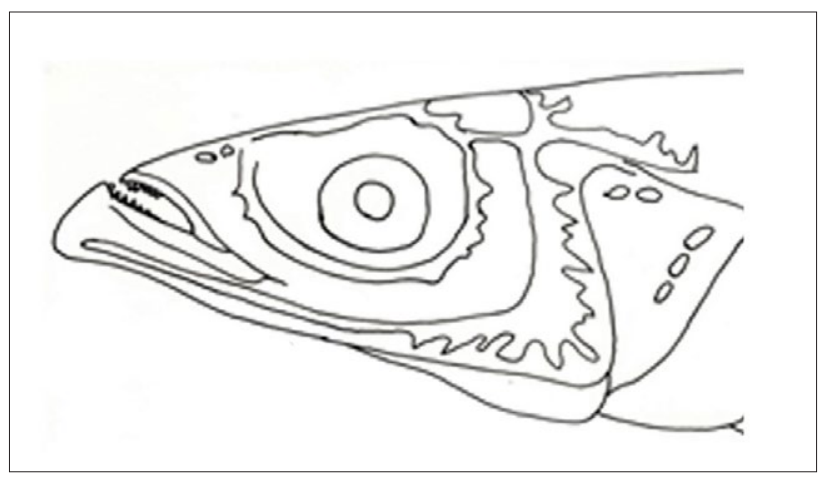

Fig. 10. Bleekeria murtii

Marine Fisheries Research Institute, Kochi, India of $126.5 \mathrm{~mm}$ (type locality: Tuticorin, India).

Paratypes: GB.5.1.1.1 in Designated National Repository, Central Marine Fisheries Research Institute, Kochi, India and 31 specimens of $\mathrm{mm} 87.2-132.3$.

Fin formula: D. 35-49, A.12-16, Ltr. 80-108

Diagnosis: Dorsal rays 35-49, lateral line scales 82-108, eye diameter 3.4\% SL, Grayish yellow on back, shading to silvery white laterally and ventrally with yellow bands, dorsal fin transparent and the interspace of rays has yellow bands. The species has a torpedo-shaped body with lower jaw protruding than the upper jaw. It has 35-49 dorsal soft rays; 12-16 anal soft rays, 56-75 vertebrae, no pelvic fins and lateral line scales 80-108. Scales absent from a medium band anterior to the dorsal fin and from the musculature at the base of caudal fin. It is characterized by a longer head and shallower body as compared to other species in the genus. The colour pattern is also different from other species.

Description: As compared to the other species in this genus the present species has fewer rays and other counts. Scales above and below the lateral line and branchiostegal rays are almost constant. Body proportions like head length (17.95-23.8); head width (4.12-10.45); pre-orbital length (4.97-9.14); eye diameter (2.4- 4.46); post orbital length (6.96-12.30); body depth (9.32-12.5); body width (10.55- 
15.45); lower jaw length (1.73-11.94); upper jaw length (1.73-11.94) as percentage of standard length. Whereas the head width 20.1-41.7; eye diameter 10.3-23.7; pre-orbital length 22.8-39.6; post orbital 33.6-56.6 as percentage of head length.

Eyes are small with an eye diameter of 2.4 to 4.4 in SL. Lower jaw projecting, pointed when viewed from above and slightly rounded from the sides. Upper jaw length 6.38-58.7 in $\mathrm{HL}$; premaxilla protrusible; mouth oblique; minute teeth in jaws and palate. Nostrils on upper side of snout anterior to eye, half way between orbit and front of snout. Gill opening broad; the dorsal end at the level of the upper edge of eye, the anterior end nearly reaching at vertical through centre of eye. No spines on opercle; scales small, thin, cycloid and arranged in forming diagonal straight lines of anterodorsal-postero dorsal direction. Lateral line high on the body ascending from the end of the gill opening to below the origin of dorsal fin, then passing parallel to the upper part of the body.

Colour: Grayish yellow on back shading to silvery white laterally and ventrally with yellow bands formed by continuous and discontinuous yellow bands. Sexual dimorphism is seen in this species. The margins of the anal fin of the adult female are dark and male is white. The upper half and lower half of the caudal peduncle is greyish white and the middle band is yellow in colour. The yellow bands in the body continuously run to the middle portion the caudal peduncle to join the yellow band. The dorsal fin is transparent and the interspace between rays has yellow bands. The specimens below $90 \mathrm{~mm}$ the yellow bands and other body colouration are less intense and as the fish grows the colour intensity increases.

Distribution: The present record of the species shows that its distribution is limited to India only.

Ecology: Like other members of the genus Bleekeria murtii are found over sandy bottoms of depth between 20-50 m. They form schools and protect themselves from their preys by burying. Predators include tuna Euthynnus affinis and carangids.

Remarks: Bleekeria murtii can be easily distinguished from other species by dorsal rays 35-49, lateral line scales 82-108, eye diameter $3.4 \% \mathrm{SL}$, greyish yellow on back, shading to silvery white laterally and ventrally with yellow bands, dorsal fin transparent and the interspace of rays has yellow bands.

Bleekeria kallolepis: Dorsal rays 40-41; lateral line scales 100; eye diameter $4.3 \% \mathrm{SL}$; back and upper body bluish; with five yellowish horizontal bands. Dorsal fins with bluish base and yellow bands and anal with a bluish band. B. profunda: Dorsal rays 49; pectoral-fin rays 16 ; teeth present in the jaws; short pelvic fins (4.2 in $\mathrm{HL}$ ) and 151 lateral-line scales.

6. Bleekeria profunda Randall and Ida, 2014 (Fig. 11, 12)

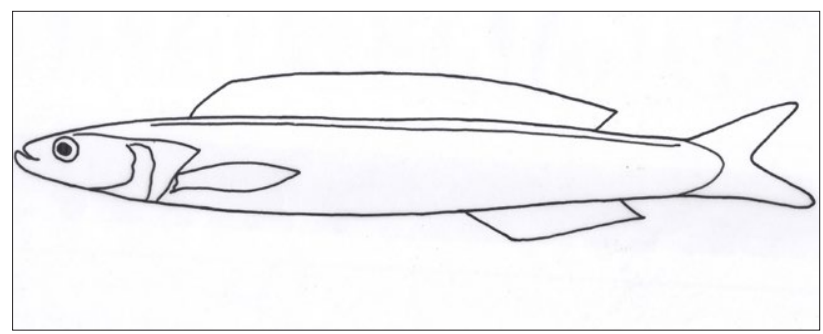

Fig. 11. Bleekeria profunda Randall and Ida, 2014

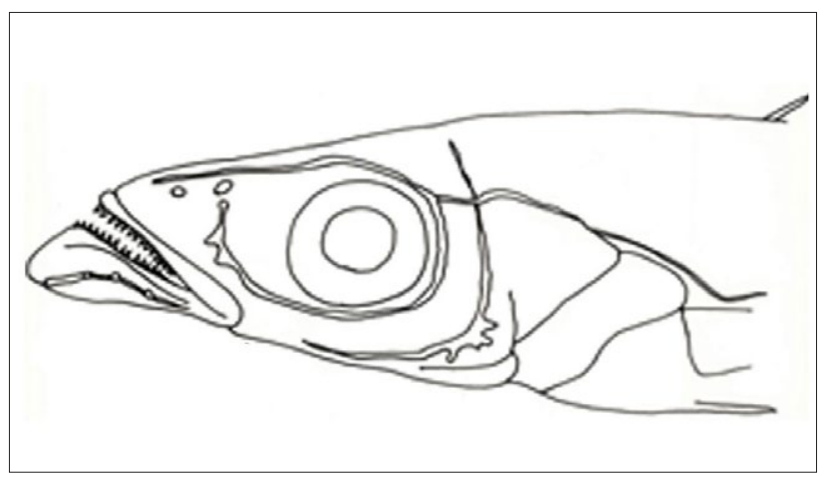

Fig. 12. Bleekeria profunda

Bleekeria profunda Randall and Ida, 2014. J. Ocean Sci. Found., 12:11. (type locality: Saya de Malha Bank)

Holotype: SAIAB 84114

Fin formula: D. 49, A. 20, Ltr. I . 151

Diagnosis: Dorsal-fin rays 49; anal-fin rays 20; pectoral-fin rays 16 ; pelvic fins 5 rays 5 ; lateral line scales 151 ; gill rakers $8+21$ vertebrae 62; eye large; mouth oblique and moderately large, the upper-jaw length 3.65 in $\mathrm{HL}$; mouth forming an angle of about $40^{\circ}$ to axis of body; small and slender teeth in the jaws; pelvic fins small, dorsal half of body pale yellowish brown, the scales narrowly edged in blackish, except on lateral line; ventral half of body pale yellowish white (Randall and Ida, 2014).

Description: Eyes large; nostrils anterior to upper fourth of eye; head and body compressed; body depth more compressed posteriorly with a slight ventrolateral skin fold; lower jaw is prominent and slightly longer; lower jaw protruding a half of eye diameter in front of snout; lower jaw is triangular in dorsal view; upper jaw oblique forming an angle of $40^{\circ}$ to 
horizontal axis of body; teeth are small, slender, conical and well-shaped in lower end; gill rakers long; dorsal fin rays 49; anal fin rays 20; pectoral fin rays 16 ; pelvic fin rays 5 ; lateral line scales 151; gill rakers $8+21$; origin of dorsal fin above tenth lateral line scale; origin of anal fin below $33^{\text {rd }}$ lateral line scale.

Colour: Grayish blue on dorsal side; with whitish lateral line; inter-orbital blue; snout; jaws; ventral, head dark red.

\section{Distribution: Saya de Malha bank}

Remarks: The presence of pelvic fins, ctenoid scales, teeth in jaws; deep body; low counts of dorsal, anal fin rays, complete cephalic sensory lateralis system present in $B$. profunda makes it a primitive status in the genus (Randall and Ida, 2014). $B$. profunda is easily distinguished from these species by its more elongated body, which correlates with its highest counts of 62 vertebrates (the other species with fewer than 58 ). Also, it has 49 dorsal rays, compared to fewer than 43 for the other species of the genus (Randall and Ida, 2014).

B. estuaria: Dorsal-fin rays 42 , anal-fin rays 15 , pectoral-fin rays 14 , a short head, long pectoral fins, no pelvic fins, 99 lateral-line scales, a single scale dorsally on the preopercle, two scales dorsally on the opercle, and teeth present in the jaws.

B. viridianguilla: Dorsal rays 40-42, lateral line scales 108-111, eye diameter $4.7 \% \mathrm{SL}$, back and upper body broccoli brown, sides and below pale vinaceous to whitish, no yellow bands, fins transparent without band.

\section{Acknowledgements}

We are grateful to Dr. A. Gopalakrishnan, Director, CMFRI, Kochi for the support and encouragement during the course of this study. We thank Dr. P. C. Heemstra of SAIAB, Dr. Bruce B. Collete of NMNH, Dr. W. N. Eschmeyer of CAS for providing pertinent information on species verification and providing information on type specimens. The authors also wish to express sincere thanks to Shri. K. M. David, Technical Assistant (Artist), CMFRI, Kochi for his help in the preparation of line drawing of the specimens.

\section{References}

Abraham, K. J., K. K. Joshi and V. Murty Sriramachandra. 2011. Taxonomy of the fishes of the family Leiognathidae (Pisces, Teleostei) from the West coast of India. Zootaxa, 2886: 1-18.

Bean, T. H. 1895. Description of a new fish Bleekeria gilli. Proc. U. S. N. M., 17: 629630.

Collette, B. B. 2001. Ammodytidae. In: (Carpenter and Niem (Eds.), FAO species identification guide for fishery purpose-Western Central Pacific, FAO, ROME, p. 3518.

Collette, B. B. and J. E. Randall. 2000. Ammodytoides leptus, a new species of sand lance (Teleostei: Ammodytidae) from Pitcarin Island. Proc. Biol. Soc. Wash., V, 113 (2): 397-400.

Duncker, G. and E. Mohr. 1939. Revision der Ammodytidae. Mitt. Zool. Mus. in Berlin, 24: 8-31.

Eschmeyer, W. N., R. Fricke and R. van der Laan. 2017. Catalog of fishes: genera, species, references. http://researcharchive. calacademy.org/ research/ ichthyology/ catalog/ fishcatmain. asp). Electronic version accessed 21. 04. 2017.

Fowler, H. W. 1931. Studies of Hong Kong fishes no. 2. Hong Kong Nat., 11(4): 287317

Goren, M. and M. Dor. 1994. An updated checklist of the fishes of the Red Sea. CLOFRES II. The Isr. Acad. Sci. \& Hum, Jerusalem, 120 pp.

Günther, A. 1862. Catalogue of the Fishes in the British Museum. Catalogue of the Acanthopterygii, Pharyngognathi and Anacanthini in the collection of British Museum, British Museum of Natural History, London, 384-387.

Ida, H., P. Sirimontapon and S. Monkoprasit. 1994. Comparative morphology of the fishes of the family Ammodytidae with description of two new genera and two new species. Zool. Stud., 33(4): 251-277.

Jordan, D. S. and B. W. Evermann. 1902. Notes on the collection of fishes form the Island of Formosa. Proc. U. S. N. M., 25, 334 pp.

Jordan, D. S. 1903. Supplementary note on Bleekeria mitsukurii, and on certain Japanese fishes. Proc. U. S. N. M., 26: 693 pp.

Joshi. K. K., P. U. Zacharia and P. Kanthan. 2012. Description of a new sand lance species, Bleekeria murtii (Perciformes: Ammodytidae) from India. Indian J. Fish., 59(2): 101-107.

Krishnan, S. and S. S. Mishra. 1993. On a collection of fish from Kakinada-Gopalpur sector of the east coast of India. Rec. Zool. Surv. India, 93 (1-2): 201-240.

McCulloch, A. R. and E. R. Waite. 1916. Additions to the fish fauna of Lord House Island. No.5. T. Royal Soc. South Aust., 40: 437-451.

Nakabo, T. 2002. Fishes of Japan with pictorial keys to the species, English edition. Tokai University Press, $866 \mathrm{pp}$.

Pietsch, T. W. and C. P. Zabetian. 1990. Osteology and interrelationships of the sand lances (Teleostei: Ammodytidae). Copeia, 1990 (1): 78-100.

Randall, J. E. and P. C. Heemstra. 2008. Ammodytes xanthops, a new species of sand lance (Perciformes: Ammodytidae) from Mozambique. Smithiana, 9: 21-25.

Randall, J. E. and J. L. Earle 2008. Two new Indo-Pacific sand lances of the genus Ammodytoides (Perciformes: Ammodytidae). Pac. Sci., 62 (4): 603-612.

Randall, J. E., H. Ida and J. L. Earle. 1994. Ammodytoides pylei, a New Species of Sand Lance (Ammodytidae) from the Hawaiin Islands. Pac. Sci., 48 (1): 80-89.

Randall J. E. and H. Ida. 2014. Three new species of sand lances (Perciformes: Ammodytidae) from the south West Indian Ocean. J. Ocean Sci. Found., 12: 1-11.

Smith, J. L. B. 1957. Four interesting new fishes from South Africa. S. Afr. J. Sci., 53(8): 219-222.

Suzuki, T. and M. Hosokawa. 1994. First record of the fish species from the Sea of Japan I. O. P. Diving News, V.5 (4): 2-6. 